\title{
A new regime of carbon counting: the practices and politics of accounting for everyday carbon through C02e
}

Article

Accepted Version

Creative Commons: Attribution-Noncommercial-No Derivative Works 4.0

Ormond, J. and Goodman, M. K. (2015) A new regime of carbon counting: the practices and politics of accounting for everyday carbon through C02e. Global Environmental Change, 34. pp. 119-131. ISSN 0959-3780 doi:

https://doi.org/10.1016/j.gloenvcha.2015.04.011 Available at https://centaur.reading.ac.uk/56230/

It is advisable to refer to the publisher's version if you intend to cite from the work. See Guidance on citing.

To link to this article DOI: http://dx.doi.org/10.1016/j.gloenvcha.2015.04.011

Publisher: Elsevier

All outputs in CentAUR are protected by Intellectual Property Rights law, including copyright law. Copyright and IPR is retained by the creators or other copyright holders. Terms and conditions for use of this material are defined in the End User Agreement.

www.reading.ac.uk/centaur 
Central Archive at the University of Reading

Reading's research outputs online 


\title{
A new regime of carbon counting: The practices and politics of accounting for everyday carbon through $\mathrm{CO} e$
}

\author{
May 2015 \\ Jim Ormond (King's College London, Geography) \\ and \\ Mike Goodman (University of Reading, GES) \\ Draft paper accepted and forthcoming in Global Environmental Change \\ Please do not quote or cite without the authors' permission
}

\begin{abstract}
Inspired by the commercial desires of global brands and retailers to access the lucrative green consumer market, carbon is increasingly being counted and made knowable at the mundane sites of everyday production and consumption, from the carbon footprint of a plastic kitchen fork to that of an online bank account. Despite the challenges of counting and making commensurable the global warming impact of a myriad of biophysical and societal activities, this desire to communicate a product or service's carbon footprint has sparked complicated carbon calculative practices and enrolled actors at literally every node of multi-scaled and vastly complex global supply chains. Against this landscape, this paper critically analyses the counting practices that create the 'e' in ' $\mathrm{CO}_{2} \mathrm{e}$ '. It is shown that, central to these practices are a series of tools, models and databases which, in building upon previous work (Eden 2012; Star and Griesemer 1989) we conceptualize here as 'boundary objects'. By enrolling everyday actors from farmers to consumers, these objects abstract and stabilize greenhouse gas emissions from their messy material and social contexts into units of $\mathrm{CO}_{2} \mathrm{e}$ which can then be translated along a product's supply chain, thereby establishing a new currency of 'everyday supply chain carbon'. However, in making all greenhouse gas-related practices commensurable in enrolling and stabilizing the transfer of information between multiple actors these objects oversee a process of simplification reliant upon, and subject to, a multiplicity of approximations, assumptions, errors, discrepancies and/or omissions. Further the outcomes of these tools are subject to the politicized and commercial agendas of the worlds they attempt to link, with each boundary actor inscribing different meanings to a product's carbon footprint in accordance with their specific subjectivities, commercial desires and epistemic framings. It is therefore shown that how a boundary object transforms greenhouse gas emissions into units of $\mathrm{CO}_{2} \mathrm{e}$, the outcome is of distinct ideologies regarding 'what' a product's carbon footprint is and how it should be made legible. These politicized decisions, in turn inform specific reduction activities and ultimately advance distinct, specific and increasingly durable transition pathways to a low carbon society.
\end{abstract}

"The government are very keen on amassing statistics - they collect them, add them, raise them to the $n ' t h$ power, take the cube root, and prepare wonderful diagrams. But what you must never forget is that every one of those figures comes in the first place from the chowty dar [village watchman] who just puts down what he pleases."

Sir Josiah Stamp - 1929 


\section{Introduction}

In research analyzing the rise of the so-called 'new' carbon economy (Brown and Corbera 2003; Boyd et al. 2011; Bailey and Wilson 2009; Leach and Scoones 2013), attention has gravitated to the practices by which units of carbon have been constructed and made commensurable in order to facilitate a series of inter-connected pricing and trading mechanisms (Boyd et al. 2011). This has most notably been the case with the critical analysis of the clean development mechanism (CDM) (e.g. Newell and Bumpus 2012; Gutiérrez 2011) and the voluntary carbon offsetting market (e.g. Bailey et al. 2011; Lansing 2013). An important component of this work has examined the tools developed to count and account for specific greenhouse gas (GHG) emissions and/or sequestrations including, for example, those from reforestation programs (Leach and Scoones 2013; Gutiérrez 2011), renewable energy projects (Bumpus 2011; Phadke 2011) and stove replacement initiatives (Simon et al. 2012).

However it is not only these 'iconic' GHG emissions within international market structures that are being counted and made commensurable. Rather, inspired by the desire of global brands and retailers to understand, reduce and, perhaps most importantly, communicate the global warming impact of their products and services, $\mathrm{GHG}$ emissions-in units of $\mathrm{CO}_{2} \mathrm{e}$-are increasingly being counted and made knowable at the mundane sites of everyday production and consumption. Indeed, such is the scale of this "product and service carbon footprinting", that one can now compare the global warming impact of a pair of jeans $\left(32.3 \mathrm{kgCO}_{2} \mathrm{e}\right.$ [Levi Strauss \& Co 2009]) with a liter of orange juice $\left(640 \mathrm{gCO}_{2} \mathrm{e}\right.$ [Tesco 2012]), a football match (5160tonnes $\mathrm{CO}_{2} \mathrm{e}$ [Carbon Trust 2013]) with a hotel bed $\left(103 \mathrm{kgCO}_{2} \mathrm{e}\right.$ [Whitbread 2009]) and an online newspaper $\left(300 \mathrm{gCO}_{2}\right.$ e [Guardian 2010]) with the delivery of money to an automated teller machine $\left(5.5 \mathrm{kgCO}_{2} \mathrm{e}\right.$ [Loomis 2011]).

Set against this backdrop, this paper considers how, by turning things into numbers (Barnes and Hannah 2001; Elden 2007), the greenhouse gas emissions from everyday activities as diverse as boiling a pint of milk to ploughing a field - each of which generates or sequesters different atmospheric gases at different historical and geographical scales - can be rendered visible, commensurable and ultimately knowable. Specifically, considering the practices of carbon counting and commensuration in relation to a pint of semi-skimmed milk ${ }^{1}$, we ask the following questions: (1) Who is undertaking these acts of everyday carbon counting and how are they enrolled in this process? and (2) How are the GHG emissions of diverse everyday practices, products and services intrinsic to a pint of semi-skimmed milk being rendered legible and commensurable?

\footnotetext{
${ }^{1}$ Semi skimmed milk - made when cream (or milkfat) is removed from whole milk - is the most popular type of milk in the UK and has a milkfat content of $1.7 \%$, compared to a minimum of $3.5 \%$ in whole standardized milk.
} 
In answering the first question, we show that while processes of supply chain carbon footprinting are not necessarily a new thing (Finkbeiner 2009), the recent surge in reporting this information to the public (as a product's "carbon footprint") has resulted in a greater number and diversity of organizations looking beyond their direct emissions to those occurring along their product or service's value chain. Consequently, in addition to carbon counting as enacted by financial intermediaries, the duty of measurement and calculation is increasingly falling to, or being adopted by, supply chain actors responsible for the fleshy, messy and indeterminate stuff of everyday life (Katz 2004). From farmers in Sweden measuring the daily methane emitted by their cows, to glass manufacturers in China calculating their product's carbon intensity as part of everyday supply chain interactions, to corporate-funded studies estimating the GHG impact of their customers' everyday consumption choices, carbon is progressively being made legible by, and assigned to, a multitude of actors across complex supply chains and networks. Crucially, this 'duty to measure' is creating a model of self-allocation which differs significantly to the existing models of governance for the new carbon economy in which institutional structures and international bodies (e.g. IPCC) determine baselines and a nation, organization or individual's future rights to emit (Lovell et al. 2013; Knox-Hayes 2010; Schroeder and Lovell 2012).

In parallel, we examine the practices by which the "messy materiality" (Prudham 2007, 414), of GHG emissions are rendered legible as discrete entities by these everyday actors. Here, previous literature has focused on the financial tools through which carbon emissions or sequestrations are spatially abstracted and packaged into commodified forms so that they may be traded in global systems of exchange (Bumpus 2011; Bailey et al. 2011; Lovell and MacKenzie 2011). Whilst valuable in showing how a unit of $\mathrm{CO}_{2} \mathrm{e}$ becomes akin to a unit of money, oil or gold (Paterson and Stripple 2012) this analysis has centered on the calculation, quantification and commensuration of those emissions, which can become "resources ready for exploitation" and value generators (Eden 2012, 1015). Specifically, this has traced the quantification of GHG emissions which can most easily be integrated into market structures, either those that the public, through moral obligations, are most willing to pay for (e.g. offsetting travel emission [Bumpus 2011]) or those, that are already subject to national or international government policies (e.g. trees through REDD [Gutiérrez 2011]). Product and service carbon footprinting -as the topic of this paper- extends the practices of carbon counting far beyond these iconic emissions to the site of the mundane and the scale of the everyday.

Without money as the central referent (i.e. Robertson 2000) and without people and sites connected through the market (Lohmann 2009), the calculation and commensuration of GHG emissions from products and services does not simply "borrow from existing financial practices" (Descheneau and Paterson 2012, 665). Rather in discussing how supply chain carbon literacy is established, and thus answering this paper's second question, we explore 
and analyze the series of tools, databases and models that enroll supply chain actors into acts of carbon counting by anchoring measurement in pre-existing or everyday frameworks and language designed to "render the unfamiliar, familiar" (Whitmarsh et al. 2011, 63; Lorenzoni et al. 2007). Able to live in and facilitate exchange between multiple worlds, we conceptualize these tools as 'boundary objects' (Star and Griesemer 1989).

By adopting this lens, we also speak to wider debates relating to the practices of environmental measurement as, for instance, in the writings of Eden (2012) and Ward (2013). Specifically we demonstrate that whilst boundary objects are "plastic enough to adapt to local needs and constraints of the several parties employing them" (Star and Griesemer 1989, 393), this plasticity is contingent upon their purpose and the actors using them. Here, we argue that although carbon counting boundary objects have the same purpose - to translate biophysical and social activities into units of $\mathrm{CO}_{2} \mathrm{e}$ - the results that are generated represent the processes by which different interests utilize the boundary object's plasticity to deal with the messiness (Prudham 2007) and uncooperativeness (Bumpus 2011) of the social worlds they are required to bridge. Indeed, as warned by Lövbrand and Stipple (2011) carbon stocks and flows are not pre-given, lying there waiting to be revealed. Rather, they have to be discovered, constructed and made visible and done so in particular and particularized ways.

In utilizing the concept of plasticity, we define it as the degree to which an object is able, and required to, adapt, stretch and accept different meanings across the actors and worlds it seeks to span/bridge. Specifically it is shown that, in order to enroll and stabilize the translation of information among multiple actors, boundary objects oversee a process of simplification, in which some things are included and other excluded, with silences produced and potential points of contestation overlooked. As Callon $(1998,2009)$ puts it, when speaking of framing and the subsequent overflowing of externalities, every attempt to bring something inside creates new outsides. Once enrolled, to meet the information requirements of actors and interests from the multiple sides of a carbon counting boundary, the tools become subject to the agendas of the worlds that they link, with each boundary actor inscribing different meanings to a product's carbon footprint in accordance with their subjectivities, commercial desires and epistemic framings. Finally by embedding measurement into the sites of everyday production and consumption, boundary objects adjudicate over complex methodological debates, simplify multifaceted biophysical processes and establish artificial boundaries and categories. As a consequence, and as outlined by "Stamp's law" which opened this paper, boundary objects are reliant upon, and subject to, any number of deliberate and/or accidental 'fudge factors' (Lohmann 2005).

Therefore, by discussing how, and by whom, everyday carbon is made legible-in this case for a pint of semi-skimmed milk - this paper offers two novel contributions to the ongoing debates surrounding the practices and governance of the new carbon economy. Firstly, it is shown that carbon is not just counted and made commensurable at the scale of 'iconic' 
emissions or reductions as part of large-scale and diffuse carbon market-making. Rather, through boundary objects, carbon is being made legible through the objects of everyday life from kitchen forks to bank accounts. Secondly by enrolling actors from across a product's supply chain and driven by the commercial desire to make all GHG emissions commensurable, the calculation of a product or service's carbon footprint has expanded the stock and flows of carbon amendable to control, triggering new forms of supply chain governance. On one hand, this results in global retailers and brands propagating distinct ideologies of just exactly what a product's carbon footprint is and is made of and the practices that go into counting it as well as how it should be reduced. On the other hand, this sees the distinct accumulation and spread of climate mitigation responsibility and risk along a product's supply. In short, supply chain carbon counting not only transforms the emissions of everyday biophysical and social activities into calculable quantities, but, permitted by the plasticity of boundary objects and shaped by competing interests of their users, also advances particularly politicized pathways for the transition to a low carbon society.

The material presented here is derived from a wider research project into the governance, practices, and politics of product carbon footprinting (Ormond 2013; 2015 in press). Whereas existing studies into product carbon footprinting have focused on technical discussions and debates (Weidema et al. 2008; Peters 2008), this research examines the on-the-ground practices by which it has been implemented. Between September 2011 and September 2013, interviews were conducted with over 100 stakeholders central to the development and implementation of product carbon footprinting. The stakeholders were identified through snowballing a sample of existing contacts, known practitioners, web searches, and involved discussions with industry experts, including key decision-makers who represented national governments, nongovernmental organizations (NGOs), standards institutions, industry associations, and global and national corporations. The majority (approximately 50 percent) of the participants were based in the UK and the USA (approximately 20 percent), with representatives also from Australia, Argentina, Belgium, Brazil, Canada, China, France, Germany, Japan, Jordan, New Zealand, South Korea, Sweden, Switzerland and Uganda.

Interviews were conducted in person and by telephone, and followed a semistructured format designed to generate evidence about ongoing processes of carbon footprinting (Schoenberger 1991; Clark 1998). This methodological approach was adopted to compliment the study's wider goal of understanding different participants' representation of reality and how the production of knowledge (re)produces power and governance structures (Dean 1999). In line with the request of the majority of participants, individuals and organizations are treated anonymously. Along with evidence gained from attending relevant meetings and workshops and supplementary corporate literature, for each interview, detailed notes were taken, transcripts were coded, and a copy was sent to participants for their verification and additional clarification. Approved transcripts were then analyzed by content, a methodological practice designed to systematically identify common patterns and properties within the data 
(Neuendorf 2002).

Of particular relevance to this article is the insight provided by actors associated with the production and consumption of milk. This sample of participants ( $n=$ approximately 35 ) included representatives from farmers and farming industry associations, processors, packaging companies, retailers, consumer representatives and agricultural intermediaries and carbon measurement consultants. In interviewing these stakeholders, emphasis was placed on understanding the practices by which data was collected, collated and translated between actors - thereby reflecting the study's goal to understand how a unit of $\mathrm{CO}_{2} \mathrm{e}$ is produced by different actors in different geographical sites and different social contexts - including the tools used and the challenges associated with translating everyday activities into stocks and flows of $\mathrm{CO}_{2} \mathrm{e}$.

We begin by providing a brief review of the practices and actors previously identified in making carbon commensurable. In doing so, we draw attention to how product and service carbon footprinting has been prompted by and, in parallel, facilitated the development of a new market for tools to count and make legible the emissions from everyday activities. We then turn to the case study of a pint of semi-skimmed milk, and consider three acts of carbon counting performed by three different sets of actors at three different stages of the value chain: these are raw material production, manufacturing and processing, and the combined categories of retail and use by consumer. For each of these stages, we highlight that whilst the plasticity of the boundary object is critical to enroll new actors and make diverse GHG emissions commensurable, it simultaneously creates distinct and politicized representations of milk's global warming impact. This, in turn, shapes the reduction agenda across the pint of milk's supply chain. We conclude by discussing the wider implications of these representations, highlighting that in a world in which everything has a comparable carbon footprint, the currency of $\mathrm{CO}_{2} \mathrm{e}$ - with the 'e' standing for 'equivalent-is increasingly used as an important management tool. Empowered by ideologically-derived numbers, global brands and retailers are justifying pathways to a low carbon society which fit their commercial agendas and which work to transform our relationships with the natural and social worlds specifically through goods, which, in turn, begin to set in motion newly imagined lifestyles and consumption behaviors.

\section{Moving from 'iconic' to 'everyday' carbon}

There is a rich literature that grapples with how, and by whom, different things are made the 'same', from compensation payments making physical injuries comparable (Radin 1993), indicators weighing the risks associated with disaster risk reduction strategies (Cardona 2011) to unwritten ratios used by parents to equate number of hours with 'quality time' spent with children (Hays 1996). Environmental geographers have joined this debate by discussing the commensurability (Espeland and Stevens 1998) of environmental resources, including 
water (Bakker 2005), biodiversity (McAfee 1999), fish (Mansfield 2003) and wetlands (Robertson 2004) ${ }^{2}$. Discernible across this latter literature is that, for diverse phenomena to be made the same, a standardized, commensurable unit of nature must first be constructed which renders the "messy materiality of life legible as discrete entities, individuated and abstracted from the complex social and ecological integuments" (Prudham 2007, 414). For instance St. Martin (2005) and Eden (2012) consider how through acts of quantification 'fish' become abstract private resources, Demeritt (2001) discusses how statistical measurement enframes the 'forest' into a calculable quantity, whilst Robertson (2004) examines the challenges associated with constructing a measurable unit of value for a 'wetland'.

With public eyes increasingly fixated on anthropogenic climatic change - despite the complex biophysical properties (not least 'invisibility') and having social relations embedded in different territories, histories, economies and political contexts (Goodman and Boyd 2011) - attention has turned to the commensurability of greenhouse gas emissions (Bumpus 2011). Here the creation of a standardized unit of carbon dioxide equivalent or $\mathrm{CO}_{2}$ "e" has facilitated the global commensurability or fungibility (MacKenzie 2009) of GHG emissions stretching from biogenic carbon stored in trees in Brazil to carbon dioxide released from coal power plants in Germany, methane captured and burned by municipal waste facilities to the carbon dioxide, nitrous oxides and water vapor released during air-travel (Bumpus and Liverman 2008). In describing these acts of carbon commensuration, authors and commentators have focused on how the ton of carbon is invented, abstracted and monetized into something sellable via a financial standardized product (Descheneau 2012). For instance Dalsgaard (2013) describes how individuals' voluntarily offset their travel emissions by purchasing carbon credits which fund carbon mitigation projects e.g. heat-efficient cooking pots in Africa. While Bumpus (2011) explains how avoided carbon emissions from renewable energy are spatially abstracted into commodities, placed into wider systems of exchange and traded on international markets eventually to offset emissions produced under distinctly different socionatural conditions.

Central to this literature is the understanding that GHG emissions can be made legible through the careful applications of accounting approaches and techniques "borrowed from existing financial practices" (Descheneau and Paterson 2012, 665; Lovell and MacKenzie 2011). To this end, the new carbon economy simply represents "business as usual" for accountants (Bailey and Wilson 2009, 2332), banks and brokerages (Knox-Hayes 2010), and other financial intermediaries. Positioning financial accounting as the home of carbon management (Bebbington and Larrinaga- González 2008; Cook 2008; MacKenzie 2009) however betrays a wider predisposition within the carbon economy literature. Focused on the tantalizing possibility that carbon may become the world's biggest commodity market (Kanter 2007) - or that climate change is the greatest market failure ever seen (Stern 2007) -

\footnotetext{
${ }^{2}$ See also Castree 2003
} 
attention has disproportionately fixated on counting those GHG emissions which can be integrated into financial market mechanisms. For instance discussions on emission trading schemes (e.g. Knox-Hayes 2010; Bullock 2012), the clean development mechanism (e.g. Newell and Bumpus 2012) and the market for voluntary carbon offsets (e.g. Bailey et al. 2011) all gravitate towards counting and making commensurable those specific and often iconic emissions which can be integrated into financial transactions for such things as trees (Leach and Scoones 2013), renewable energy (Bumpus 2011; Phadke 2011) and cook stoves (Simon et al. 2012).

However, accelerated by the wider fusion of sustainability and brand identity (e.g. Hughes et al. 2013; Dauvergne and Lister 2012), the recent uptake of product and service carbon footprinting has expanded carbon counting beyond individual iconic emissions to the mundane sites of everyday production and consumption. Here, in an attempt to create a large-scale movement in low carbon commodity and services consumption, global retailers and household brand names have sought to establish a universally accepted and commonly understood measure of the carbon footprint of products across their lifecycle. As described by former Tesco CEO Sir Terry Leahy in his speech entitled "Green grocer? Tesco, carbon and the consumer", it is this desire - to create and access a mass movement in green (low carbon) consumption - which has driven the retailer to measure and report the carbon footprint of 70,000 of its products ${ }^{3}$, and ultimately is giving rise to the notion of an currency of everyday carbon:

"...Many of those people who talk about the need for a carbon currency say it is too complicated to develop; that it will take years. However, at Tesco, we believe in action, in overcoming hurdles, in making complex problems simple... To create a mass movement in green consumption, we must empower everyone, not just the enlightened or the affluent... we must provide better information ... customers want us to develop ways to take complicated carbon calculations and present them simply... so that customers can compare their carbon footprint as easily as they currently compare their price or their nutritional profile..." Tesco (2007)

Leahy's announcement to a roomful of environmentalists, civil servants, retailers and academics (Independent 2007) and similar announcements by retailers such as Walmart (2010) and Casino (2012) have been described as heralding the start of a "green consumer revolution" (Independent 2007; Financial Times 2007). The speech also marked a pivotal point within the landscape of carbon counting. Empowered by the deployment and use of $\mathrm{CO}_{2} \mathrm{e}$ as a measurable and translatable unit, global retailers have signaled their intention to overcome seemingly impossible hurdles and shift the practice of carbon counting forevermore beyond the academic and accounting fraternity and the aforementioned iconic emissions to the site of everyday production and consumption. As a result, we argue that the

\footnotetext{
${ }^{3}$ In 2011, Tesco announced it was to curtail the consumer-facing labeling element of its carbon footprint program, although this has not stymied the measurement element of the retailer's product carbon footprinting ambition
} 
supply chain can now be seen as an additional 'regime' of carbon counting ${ }^{4}$ - where stocks and flows of carbon are constructed as administrative domains (Lövbrand and Stripple 2011).

However, if we take a step back, the shift from iconic to everyday carbon raises the following question: If the majority of a product's emissions occur outside a retailers' direct operations, who, in the words of Leahy, is being tasked with making these complicated carbon calculations and presenting them in a simple, translatable format?

\section{Who counts everyday carbon?}

Leahy's desire to create a currency of carbon highlights the need to analyze how, and by whom, everyday carbon is made visible and commensurable. Specifically, given the mundaneness of products being calculated, the myriad of biophysical, industrial and social activities along their supply chains and without money as a central act of reference, the act of carbon counting are not, and cannot, be only restricted to the various intermediaries profiting from the financial carbon markets such as the CDM, EU ETS and the voluntary offset market (Descheneau 2012; Lovell and MacKenzie 2011; Bailey et al. 2009; MacKenzie 2009). Instead, recognizing that for the organizations making these carbon commitments, the biggest impact to their product's footprints typically occurs outside their 'four walls', it becomes increasingly apparent that the introduction of product carbon footprinting is reliant upon enrolling supply chain actors. Furthermore, as described by this global manufacturing firm commenting on the introduction of their supply chain carbon measurement program, this isn't just asking suppliers to report existing data, but rather involves a more fundamental process in which whole supply chains must become carbon literate:

"... The biggest challenge we found was that the majority of our emissions were in our supply chain, and many of these were not being captured, reported or disclos[ed]... many partners do not have the knowledge or resources to do so ... Therefore a key element of our approach was to help build internal awareness along our supply chain on what their carbon footprint is and how to measure and report it..." Interview \#24

This goal of building supply chain carbon awareness and literacy resonates with existing research examining how the general public makes sense of carbon (Koteyko et al. 2010) or becomes "carbon capable" (Whitmarsh et al. 2011, 59). For instance Nerlich and Koteyko (2009) consider how climate change is integrated into existing knowledge through linguistic constructivism and carbon compounds such as carbon taxes, carbon budgets, carbon diets. Others have focused on the role of cultural symbols - the polar bear, the inconvenient truth, celebrities - in catalyzing shifts within public understanding and attempting to counterbalance the intangibility, complexity and uncertainty of climate change (Boykoff and Goodman 2009; Slocum 2004). Whilst these analyses trace how individuals engage with the everyday use of

\footnotetext{
${ }^{4}$ The other three being 'the national carbon sink', 'the carbon credit' and 'the personal carbon budget'
} 
carbon to foster low carbon personal behaviors (Whitmarsh et al. 2011), less attention has been paid to how supply chain actors are enrolled and made carbon literate to enable the everyday measurement of carbon.

To address this gap, and to complement the existing carbon literacy literature, we analyze here the enrolments of supply chain (and associated) actors in order to measure, count and make commensurable units of nature. Here, enrolment refers to an element within the mechanism of translation (Callon 1986), in which, through a set of strategies and devices, a focal actor attempts and achieves acceptance from other actors of their interests, objectives and interrelated roles through the process of bargaining, making concessions and the alignment of interests (Madon et al. 2004; Sarker et al. 2006). For instance, highlighting how anglers are enrolled as 'fish counters' Eden (2012) cites the logbook in which they record their counts; Ellis and Waterton (2005) introduce the recording machinery and reporting systems, which enroll volunteers into biodiversity action planning. And, in discussing how accountants position themselves as managers of climate change, Lovell and MacKenzie (2011) describe a series of reports, programs and activities, which attempt to make carbon understandable and relevant to the profession.

Common to each of these accounts of enrolment are specific tools, that live in and facilitate exchange between multiple worlds, blurring, for example, amateur-professional, and scientific-lay boundaries. Translating this to the calculation of a product or service's carbon footprint, our attention is directed to the series of tools and practices which have been developed, over the past five years, to support supply chain actors undertake carbon calculative practices (e.g. Carbon Trust 2009; Pe International 2009; PRe's Sima-Pro 2009). Yet in contrast to other measurement tools, these carbon-counting mechanisms face two distinct challenges. Firstly they must account for and make commensurable GHG emissions, which arise from radically different biophysical, industrial and social sources at varying atomical, geographical and historical scales and levels of 'un-cooperativity'. Secondly they are tasked with enrolling a myriad of different actors, with differing motivations - from, for example, dairy farmers in Aberdeen looking for cost efficiencies to sugar companies in Zambia seeking continued market access.

Reflecting the scale and complexity of these two challenges, we conceptualize carboncounting tools as 'boundary objects', which as Star and Griesemer $(1989 ; 393)$ describe are devices "plastic enough to adapt to local needs and the constraints of the several parties employing them". In particular this conceptual lens is used to capture how these tools are able to enroll everyday supply chain actors into acts of carbon counting and commensuration, by anchoring measurement in the language of the worlds they operate within. On the whole, this renders the unfamiliar, familiar, whilst also being capable of multiple interpretations (Kwa 2005) and serving as two-way translators (Latour 2005) for multiple users. 
This conceptual approach, and role of everyday actors in undertaking carbon calculation links to the work, of critical sociologists and anthropologists of markets such as Callon (1998) and Mitchell (2002) who engage with the accounting systems that make market exchange possible. At the core of this work is the exploration of how externalities are framed, setting the contexts within which interaction may happen and the rules and norms which guide the actors involved. Recent applications include how carbon markets are performed through different forms of economic models and methods of calculation (e.g. Callon 2009; MacKenzie 2009). For instance Lohmann (2009) discusses carbon accounting techniques required by the Kyoto Protocol and the European Union Emissions Trading Scheme, whilst Lansing (2012) discusses the framing inherent within the production of carbon offsets in Costa Rica. As Callon (1998) observes, acts of framing are active, fragile on-going processes. We argue, boundary objects, with their common narratives shared by actors at multiple sides of a boundary, help to stabilize and manage framings in a consistent, reliable way that facilitate the counting, visibility and management of everyday carbon footprinting.

Whilst boundary objects have previously been discussed in relation to the measurement and management of environmental resources (Eden 2012; Demeritt 2001; Murdoch and Ward 1997), this concept has had limited application in discussions of climate change. Studies to date have largely focused on boundary organizations and the flow of information between scientific research and public policy relating to the unique science-policy hybridity that is the Intergovernmental Panel on Climate Change (e.g. Siebenhüner [2003]; Hope [2009]; Huhme and Mahony [2010]; Fogel [2005]; see also Ascui and Lovell [2012] and Miller [2001]). Yet as Cash (2001) explains, boundary objects not only feature at the boundaries between science and public policy, but are observed between every social world and at every scale as the examples of these carbon counting tools shown in their ability to connect diverse, multi-scalar global supply chains illustrate.

To illustrate the broad conceptual points introduced and explored above, we now turn to how the GHG emissions associated with the production and consumption of a pint of semiskimmed milk are rendered visible and commensurable so that a retailer like Tesco in the UK can state that its product carbon footprint is $800 \mathrm{~g} \mathrm{CO}_{2} \mathrm{e}$ (Tesco 2008). In tracing these calculative practices we show that in order to abstract a single $\mathrm{CO}_{2} \mathrm{e}$ number from the varying, messy and uncooperative social worlds in which milk is produced and consumed, carbon counting boundary objects are exposed to multiple user requirements, competing commercial interests and methodological challenges. How the objects adapt, and are required to adapt, to these hurdles reflects an expression of their (and their creator's) ideology towards what exactly a product's carbon footprint is, which, in turn, sets in motion distinct and politicized carbon reduction pathways. 


\section{Calculating the everyday carbon of a pint of semi-skimmed milk in the} UK

Milk was chosen as the case study for this paper as the epitome of an everyday product, and with $90 \%$ of its emissions occurring outside the retailers' four wall (as shown by Figure 1 ) it is a a clear example of a retailer's need to engage a supply chain in product and service carbon footprinting. A pint of semi-skimmed milk also provides a suitable example of the multiple messy biophysical and social worlds from which GHG emissions must be abstracted. This includes making legible the methane emitted by a cow, avoiding double-counted emissions for the cream skimmed from the milk, and calculating the carbon sequestrated within a tree later used for packaging or the global warming impact of throwing away expired milk. Specifically the following section focuses on three broad stages of the pint of milk's life cycle, which, as illustrated by Figure 1, account for the three largest contributions to its footprint. Again these stages are raw material production, manufacturing and processing and the combined categories of retail and consumer use ${ }^{5}$. These stages also witness the enrolment of three different groups of actors through three different boundary objects: The first involves farmers and on-farm emissions, the second, manufacturers, processors and packaging companies, the third retailers, consumers and consumption behaviors, from getting and putting the milk on the shelf through to its disposal. It is important to note that in tracing the practices behind these calculations and numbers, this study does not dispute the empirical findings of the studies cited, rather we focus on how the global warming impact of diverse activities are made commensurable and ultimately knowable as a single product carbon footprint number in the form of $\mathrm{CO}_{2} \mathrm{e}$.

Figure 1: Carbon footprint of a pint of milk, by supply chain component

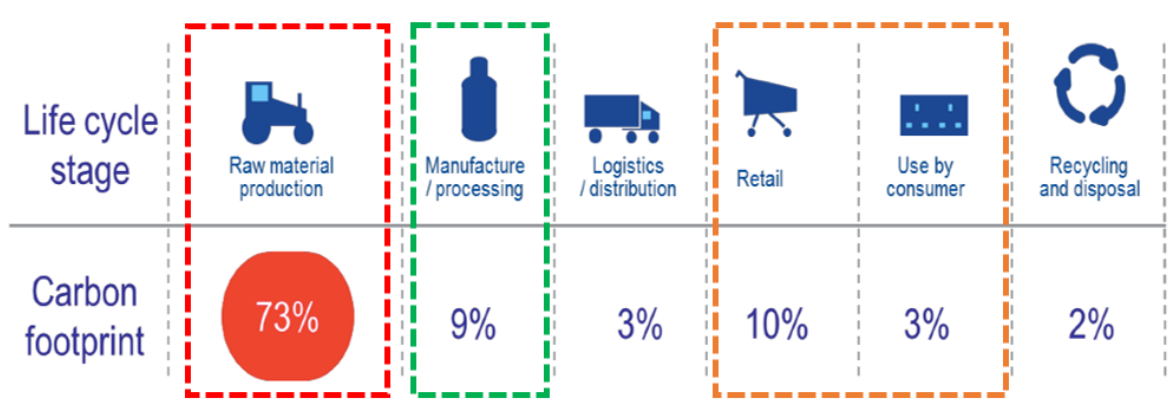

Source: Tesco (2008)

\section{Enrolling farmers to calculate the everyday carbon from cows}

The most significant contribution (typically $70-80 \%$ ) to a pint of milk's carbon footprint occurs as a result of on-farm activities (Carbon Trust 2010). These emissions are generated by

\footnotetext{
${ }^{5}$ We combined retail and use by consumer, as together they represent the second largest contribution. In addition, consumption choice and use can be seen to also include the decision on where to shop (retailer and their associated emissions)
} 
various technical and biophysical processes, each producing different greenhouse gases: onfarm electricity consumption releases carbon dioxide $\left(\mathrm{CO}_{2}\right)$, a cow's enteric fermentation generates methane $\left(\mathrm{CH}_{4}\right)$, whilst both methane and nitrous oxide $\left(\mathrm{NO}_{2}\right)$ are produced as a result of on-farm manure storage and application. Reflecting their significance, at both a product- and national-level, ${ }^{6}$ the past decade has seen increased attention paid to calculating on-farm GHG emissions. For instance the Tesco Dairy Centre of Excellence, in partnership with the University of Liverpool, have used hand-held LaserMethane Detectors ${ }^{\circledR}$ ('Burp-ometers') to measure the methane released by cows under different feeding regimes (see Chagunda et al. 2009; Chagunda 2013). Similarly the UK Government has commissioned research using respiration chambers to measure cows' daily methane emissions under different management conditions (Defra 2009).

The manual collection of data directly from source is however laborious and costly: for instance the LaserMethane Detector® has to be held three meters from a cow's mouth for five minutes, four times a day. Instead, and to expedite measurement, a series of primary data-collection models have been developed, for the dairy sector, including Agri-Assist's Carbon Footprint Tool, the Scottish Government's Dairyfootprint Dashboard, Sainsbury's Dairy GHG Model and the CoolFarm Tool, sponsored by Unilever and Heinz among others ${ }^{7}$. Whilst developed by a myriad of actors, at their core, each model seeks to enroll dairy farmers as carbon counters, typically through the premise that carbon measurement will identify cost reductions. For example Sainsbury's (2009) have reported that its carbon measurement tool helped farmers reduce their energy costs and carbon footprint by $10 \%$, while, supermarket chain Morrisons (2011) have highlighted how the Agri-Assist tool enables its dairy farmers to link lower emissions with farm profitability.

Although varying considerably in the level of input required, each of these models calculates the GHG emissions associated with on-farm practices based on data collected by farmers (or by consultants on behalf of farmers) and input into an electronic data collection format. For instance, and as illustrated by Figure 2, the Cool Farm tool is a Microsoft Excel Spreadsheet containing a series of optional and mandatory categories, for users to complete and fill in with data:

- General (e.g. farm location, climate)

- $\quad$ Crops (e.g. crop type, fertilizer use)

\footnotetext{
${ }^{6}$ it is estimated that the carbon footprint of the UK dairy sector is 15.5 million tonnes $\mathrm{CO}_{2} \mathrm{e}$ per year, approximately $2 \%$ of the UK's total emissions (McAllister et al 2011)

The Agri Assist Carbon Footprint Tool was developed by DCD Ltd, the Centre for Sustainable Energy, AEA and the Carbon Trust (Agri Assist 2009).

The Scottish Government's Dairyfootprint Dashboard was developed as part of The Scottish Governmentfunded research project to 'Identifying opportunities to reduce the carbon footprint associated with the Scottish dairy supply chain' (Scottish Government 2010).

- The Sainsbury's Dairy GHG Model was developed by AB Sustain and in 2009, became the first agriculture model to receive Carbon Trust certification against the PAS 2050 Standard (AB Sustain 2009)

The Cool Farm Tool is an online greenhouse gas (GHG) calculator, developed by Unilever and researchers at the University of Aberdeen to help growers measure and understand on-farm GHG emissions (Cool Farm Tool 2013).
} 
- Sequestration (e.g. land-use change - conversion from forest to arable)

- Livestock (e.g. livestock type, manure management practices)

- Energy Use (e.g. diesel / petrol use on farm)

- Processing (e.g. electricity used for processing, waste water generated).

Figure 2: Cool Farm Tool

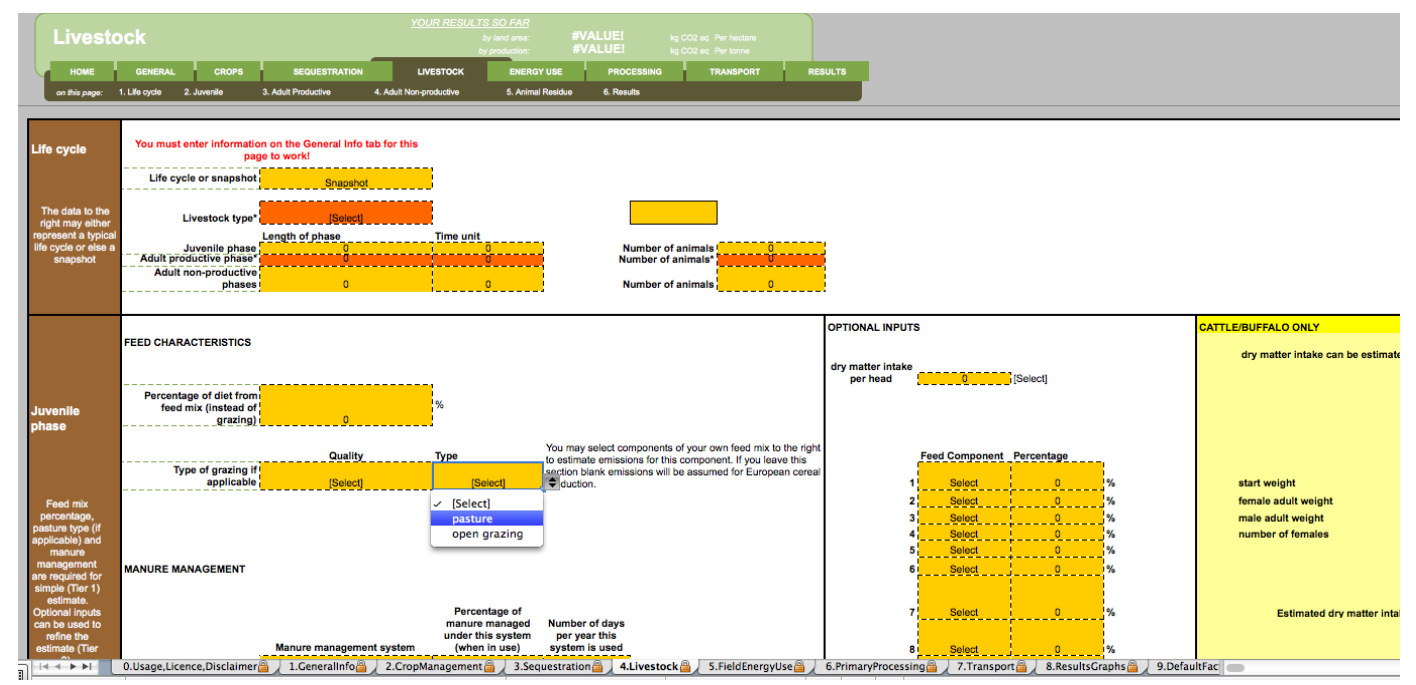

Source: Cool Farm Tool (2013)

In turn, to answer these questions, the Cool Farm tool, for example, provides a series of drop down options, e.g. users can choose from six different types of grazing - from high to low quality forage, open or pasture. The models then transform this information into units of $\mathrm{CO}_{2} \mathrm{e}$ which stipulate the average emission rate of a given emittant and its associated global warming potential (IPCC 2006). For instance, the Cool Farm tool utilizes the IPCC's methane conversion factors for seventeen different manure storage practices at temperatures ranging from $10-28^{\circ} \mathrm{C}$ and the IPCC's nitrogen excretion rates for eighteen different livestock types (from hens, horses, camels to foxes) across nine different geographical regions. Based on these calculations, farmers and retailers alike are provided with a detailed breakdown of onfarm GHG emissions, and consequently the daily methane emissions of an adult cow eating a diet of oats in Australia $\left(6.16 \mathrm{kgCO}_{2} \mathrm{e}\right.$ ) becomes comparable with the $1.16 \mathrm{kgCO}_{2} \mathrm{e}$ (released daily as nitrous oxide and methane) from one ton of un-covered slurry in Sweden and the $1.36 \mathrm{kgCO}_{2} \mathrm{e}$ released during the production of $1 \mathrm{~kg}$ of synthetic fertilizer in the UK (Hiller et al. 2011).

Located at the interface of the worlds of animals, farmers, consultants, processors, retailers 
and Governments, these data-collection models represent the first example of a boundary object that facilitates the counting of everyday carbon. On one hand by collecting and combining on-farm data with existing emission factors, the models are able to live within the world of the farmer, transforming their everyday practices into global warming impacts as expressed in units of $\mathrm{CO}_{2} \mathrm{e}$. As explained by this farmer, when describing the level of input required by a supermarket's carbon counting model, this is achieved by these models inhabiting the world of the farmer, enrolling them as data collectors by engaging them in their own language and requesting data they are familiar with and which is often already being collected:

"... The tool is focused on farm management, and - to be fair - a lot of the information is already out there - much of it we already collect, e.g. how much feed, fertilizer use, and we can get other data from invoices..." Interview \#60

In addition, by limiting responses to drop-down options the models stabilize the complexities of day-to-day milk production and animal husbandry, enabling consultants, processors, retailers and Governments to compare like-for-like GHG emissions of different on-farm practices (e.g. fertilizer application, livestock enteric emissions, farm energy use) and different points of a product's supply chain. As described by this global food manufacturer, the value of these models using globally accepted and credible emission factors is their ability to stabilize the variability of milk production. Or put simply, to render the unfamiliar activities, which occur on-farm, familiar:

"... The value of the tool is that it provides a consistent methodology to quantify, monitor and compare the climate impact of different agricultural production models, which allows us to benchmark the progress and impact of our different suppliers, from all around the world - to understand what is working and what can be improved..." Interview \#32

However, in making complex technical and biophysical on-farm processes commensurable, these primary data-collection models are plagued by the tension of being required to simultaneously meet the information requirements of actors on multiple sides of a boundary. To remain plastic enough for farmers (as data inputters), the models must simplify multifaceted biophysical processes, establishing artificial boundaries and categories. For example, while the Cool Farm model provides over 35 different fertilizers to choose from, other models -in particular those designed to provide internal farm assessments ${ }^{8}$-require significantly less detail, asking farmers only to report, for instance, the quantity of fertilizer applied, or how their manure is stored and not specify the fertilizer's nitrogen content, soil drainage, manure's composition. Whilst these simplifications and pre-determined assumptions may be necessary to enroll new carbon counters, they also restrict the level of input and obscure the intricacies of individual farm practice, as openly acknowledged by this

\footnotetext{
${ }^{8}$ For example Agri-assist's Carbon Footprint Tool and Scottish Government's Dairyfootprint Dashboard
} 
user:

"... Each day, month and year on the farm is different - there are no set rules, sometimes we give them [cows] a handful more food, for fertilizer, you use what you buy, sometimes not as much, sometimes more, I am not sure how well any model can ever capture this... "Interview \#60

In satisfying the requirements of processors and retailers (end-users) and presenting data in a format through which the impact of different global production systems can be compared, the models are required to adjudicate over complex and politicized methodological decisions. For example should farmers receive a negative emissions for carbon sequestrated when arable land is reverted to woodland? Conversely how should emissions associated with woodland converted to arable land be allocated to a farmer and their products? Despite representing a key factor in the result generated, there is a lack of uniformity in how datacollection models treat these, and other, methodological decisions ${ }^{9}$. Models principally designed for individual internal farm assessments typically do not engage with these debates, opting, instead, for the simplest solution for their users, but yet failing to capture a potentially key element in the product's footprint. Other models - in particular those required by global retailers to enable comparison across multiple farms and with other sites within the supply chain (e.g. Cool Farm tool) - grapple with these methodological challenges and adopt and propagate uncertainties and disputed classifications.

What this first example shows is that there is not a simple way to extract GHG emissions from the messy reality of the social and material worlds they inhabit. In particular, the perceived, and actual, requirements of users influence how each primary data-collection model collects and translates information across the boundaries between different farming, animal husbandry practices and end users, shaping the scope and plasticity of the model, and the assumptions and methodological decisions taken. How these models respond to these challenges results in significant discrepancies between the results generated. For instance in comparing three different models Hillier (2011) found that whilst the Cool Farm Tool and IPCC guidelines (for hand-collected data) provided similar results, the GHG emissions calculated by the CLA CALM tool were $84 \%$ higher. Indeed, even for relatively simple processes such as the GHG emissions from fertilizer use differences as great as $240 \%$ (ranging from $0.43 \mathrm{CO}_{2} \mathrm{e}$ to $1.37 \mathrm{CO}_{2} \mathrm{e} \mathrm{t} / \mathrm{ha}$ ) have been reported between different models (Lewis et al. 2013).

Crucially, in quantifying the complexities of agricultural production into a series of numbers, new pathways become available for retailers and brands to enact carbon reduction activities. Here, just as Murdoch and Ward (1997) described how statistical representations and accounting procedures brought agriculture into the formal economic sector and open for

\footnotetext{
${ }^{9}$ This includes, for example, the inclusion (or not) of capital equipment emissions and nitrate emissions from soils see Finkbeiner (2009); Plassman et al. (2010); Pan et al. (2011) for further details
} 
coordinated state intervention, so to do these carbon counting tools bring farming and agriculture firmly into the new carbon economy. Despite the ambiguities described above, empowered with supposedly commensurable numbers, retailers and brands are able to coordinate distinct new routines of carbon reduction. Here, informed by the discourse of carbon reduction equating with cost reduction, attention is focused on improving the efficiency of farming practices and animal husbandry. ${ }^{10}$ Notably, these carbon reduction activities are facilitated by the one-to-one relationship that exist between retailers and their supplier groups, in which farmers are enrolled first as carbon counters and then reduction agents. However, and as discussed in the next section, more complicated relations exist in the convoluted and extended supply chains of the processing, manufacturing and packaging of our pint of milk.

\section{Competing industry definitions of 'everyday carbon' for milk manufacturing and processing}

Moving along the supply chain, the next contribution to the carbon footprint of a pint of semiskimmed milk occurs during manufacturing and processing which has two key components. The first, the energy used to separate, pasteurize and homogenized the raw milk, accounts for approximately 4-6\% of the total footprint (Flysjö et al. 2011). The second, includes the emissions associated with the extraction of raw materials, manufacturing, transport, reuse, recycling and final disposal of a glass bottle, plastic container or cardboard carton which typically represent $5-8 \%$ of the total footprint (Flysjö et al. 2011).

Whereas on-farm data is provided by enrolled farmers through existing supply chain relationships (e.g. Tesco Sustainable Dairy Group), data on the manufacturing and processing (including packaging) stages is reliant upon a number of different actors and their distant supply chains. Further, many of these actors are unable or unwilling to share accurate primary data relating to their activities due to lack of resources, complex accounting practices or commercial sensitivities. For instance, and as explained by this packaging supplier when discussing the rise in demand for their carbon (and energy) data there exists a reluctance to divulge data up the supply chain for fear that it provides direct insight into business processes (and by proxy costs), leaving themselves exposed during future price negotiations or to market competition:

"... As a supplier you are coming up to your annual contract negotiation - in the negotiation the buyers can say, 'we know your industry, we understand the prices for raw materials and transport and therefore what it costs you to make the product and here is what we are willing to pay'. Currently they know nothing of what happens in your factory (e.g. energy costs), so you can negotiate... If suppliers give better information on this [through product carbon footprinting], then you are at a

\footnotetext{
${ }^{10}$ For instance Asda, have provided discounts on a High Sugar Grass for their farmers stating that it will increase profitability by over £10million and cut methane emission by $20 \%$ per cow (Food Bev 2011).
} 
disadvantage... if you are a supplier it doesn't do you any good to show your cards..." Interview \#32

Even when data is made available, its accuracy remains contingent on a series of complex and ambiguous factors and calculative practices. For instance, as the production of semiskimmed milk also creates cream, data collectors must collect and disclose addition data to enable the allocation of GHG emissions between these two co-products. Typically based on economic value, this allocation calculation is further complicated as changes in demand for one product affects the production volume of the other product (e.g. see Flysjö et al. 2012). Whilst for other practices within the processing stage, for example, energy usage at production sites, even when primary data is available it can be out-of-date, incomplete or simply unreliable. In short, and as this industry expert decried when asked what the biggest challenge for the mass uptake of product carbon footprinting:

"... It is a mess, suppliers are suffering from survey fatigue and many do not have resources or systems dedicated to capturing the relevant data, meanwhile convening organizations are spending an increasingly amount of time identifying, collecting, evaluating and dis-aggregating data from their suppliers just so that they can present it in a meaningful way..." Interview \#72

The challenges of collecting primary data typified by this comment has seen a rise in secondary data sources and databases over the past decade. These in turn enroll new actors into acts of carbon counting and commensuration. At one end of the spectrum, industry associations have assumed the role of a kind of 'librarian' by collecting, harmonizing, aggregating and publishing data from, and on-behalf of, their members. For example, Plastics Europe publishes GHG emissions data for 70-plus plastic products. Notably, and as this representative from the metal industry candidly explained, the objective stimulating this selfenrolment is not only to aggregate data and remove commercially sensitive details but also as part of a wider campaign to advance their industry's sustainability credentials:

"... We frequently do massive data collections, submitting datasets to trade groups we participate in, they then wrap the data set up with other suppliers to create industry averages... we don't want to just compare one facility with another, rather the most important thing is to create a favorable set of data, published as far and wide as possible..." Interview \#29

At the other end of the spectrum are a series of centralized life cycle assessment (LCA) databases, established by Government agencies, specialist consultancies and hybrid academic-government bodies such as Ecolnvent, the European Reference Life Cycle Database and the US Life Cycle Inventory Database. These centralized databases have witnessed almost exponential growth over the past decade, bringing together various data sources and providing a platform for users to compare (for a fee) the GHG emissions of 
multiple different inputs. ${ }^{11}$ In addition to bringing together multiple data sources, centralized databases also integrate each dataset into their network structures, mapping one input to another. As a consequence, a user can, by altering the parameters of their data requests, compare, for instance, the carbon impact of energy generated by wind versus solar, plastic production in France to plastic production in Germany, or, at a different level, plastic production at $5 \%$ recycled $\mathrm{PET}$ with $50 \%$ recycled $\mathrm{PET}$.

Whilst varying considerably in size and scope, these secondary databases serve to collate, aggregate and transmit the global warming impact from the multiple worlds associated with the manufacturing, processing and packaging of semi-skimmed milk (e.g. national energy generation, production of packaging materials) into a single $\mathrm{CO}_{2}$ e figure applicable to the worlds of the retailer and end user. Inhabiting these "multiple communities of practice and satisfying the informational requirements of each of them" (Bowker and Star 1999, 15), databases thereby represent the second example of this paper's carbon counting boundary objects. From the perspective of supply chain partners (e.g. energy generating companies, packaging manufacturers) databases provide a platform to convey the most favorable (i.e. lowest carbon) accounting of their global warming impact to the widest audience possible. For the convener, be they industry association, academic institute or third party consultant, databases represent lucrative or prestigious tools to enter the new carbon economy marketplace by monetizing the dissemination of data and by speaking on behalf of thousands of supply chain partners around the world. For instance, purchasing a user license for the Ecoinvent database (a single commercial license costs $\$ 2,500$ ), allows an end user to select the information they require to undertake their calculations, bypassing the need to engage with each, or indeed any, of their supply partners.

Not surprisingly, by simultaneously inhabiting, and translating information, along a product's supply chain, databases become shaped by the agendas of the multiple worlds and actors that they link. In particular driven by the commercial desire to be recognized as 'low carbon', suppliers utilize secondary databases as platforms to adopt, advocate and inscribe different meaning and interpretation as to the extent of a product's carbon footprint based on different assumptions and different forms and pathways of measurement. For example, adopting the assumption that a glass bottle can be re-used up to 30 times, data published by Owen-Illinois in 2010 (the world's largest glass manufacturer) reported that the carbon footprint of a glass beverage container is $96 \%$ and $95 \%$ lower than the same size PET and aluminum container, respectively. Alternatively, assuming that each glass bottle is only used once, a study conducted for the PET resin association in 2010 found that GHG emissions for plastic (PET) bottles are $59 \%$ and $77 \%$ less than aluminum cans and glass bottles respectively (PETRA 2010). Meanwhile, by including the 'negative' carbon sequestrated during biogenic processes and stored carbon within its calculations, a 2012 study for SIG Combibloc (one of the world's

\footnotetext{
${ }^{11}$ For instance, Ecoinvent lists data for over 400 different packaging formats including 18 different plastic packaging formats
} 
leading suppliers of carton packaging) to launch its new EcoPlus beverage carton reported that "carton packs generate around two to three times less environmentally harmful gas than disposable PET bottles".

In short, and as acknowledged by Owen-Illinois' own CEO, AI Stroucken, when discussing their latest carbon footprint figures:

"Widespread inconsistencies in carbon footprint assessments have made it nearly impossible to compare the impact of one packaging material with that of another, with many assessments used today only taking into account a portion of the full life cycle of a product, resulting in incomplete and inaccurate data. Customers are sometimes unknowingly making packaging decisions based on incomplete data" Owen-Illinois (2010)

Table 1: Different figures for carbon footprint of milk packaging

\begin{tabular}{|c|c|c|c|c|}
\hline & $\begin{array}{l}\text { Glass } \\
\text { Where data available - virgin } \\
\text { material, and variable reuse rate }\end{array}$ & $\begin{array}{l}\text { Aluminum } \\
\text { Where data available - virgin } \\
\text { material, and re-use }\end{array}$ & $\begin{array}{l}\text { Plastic } \\
\text { Where data available - virgin } \\
\text { material, and no re-use }\end{array}$ & $\begin{array}{l}\text { Carton } \\
\text { Where data available - virgin } \\
\text { material, and no re-use }\end{array}$ \\
\hline WRAP (2010) & $\begin{array}{l}\mathbf{7 0} \mathbf{k g C O} \mathbf{C O}_{2} \\
\text { per } 1000 \text { liters (re-use x 17) }\end{array}$ & - & $\begin{array}{l}\mathbf{7 9 . 7 5} \mathbf{k g C O} \mathrm{CO}_{2} \mathrm{e} \\
\text { per } 1000 \text { liters }\end{array}$ & $\begin{array}{l}74.11 \mathrm{~kg} \mathrm{CO} \\
\mathrm{CO}_{2} \mathrm{e} \\
\text { per } 1000 \text { liters }\end{array}$ \\
\hline Ghenai (2012) & $\begin{array}{l}\mathbf{3 3 9} \mathbf{k g C O} \mathbf{C O}_{2} \\
\text { per } 1000 \text { liters } \\
\text { (re-use } \times 1)\end{array}$ & $\begin{array}{l}146 \mathbf{~ k g ~ C O 2 e} \\
\text { per } 1,000 \text { liters }\end{array}$ & $\begin{array}{l}\text { 276kg CO2e } \\
\text { per } 1,000 \text { liters }\end{array}$ & 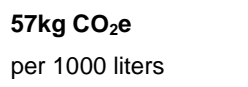 \\
\hline $\begin{array}{l}\text { Gujba and Azapagic } \\
\text { (2011) }\end{array}$ & $\begin{array}{l}\text { 180kg CO2e } \\
\text { per } 1,000 \text { liters (re-use x 15) }\end{array}$ & - & $\begin{array}{l}\mathbf{1 6 0 k g ~ C O 2 e} \\
\text { per } 1,000 \text { liters }\end{array}$ & $\begin{array}{l}\text { 90kg CO2e } \\
\text { per } 1,000 \text { liters of milk }\end{array}$ \\
\hline
\end{tabular}

Consequently, whilst secondary databases fill important gaps in primary data, the contested nature of a product's carbon footprint predicates a complex interplay between data collection and data dissemination. Advanced by competing industry and industry association interests, datasets adopt contesting definitions of what should be included or excluded in a product's carbon footprint which results in a proliferation of conflicting carbon footprint figures for literally the same object. This is clearly illustrated by Table 1, which summarizes three sets of reported packaging data. Crucially, despite the differing definitions, these published data sources remain largely unchallenged publicly (outside specific industry debates), with the often intense power struggles over the technical debates and rules that define a carbon footprint obscured. The result, and as forewarned by Al Stroucken above, is that end-users engage uncritically with these repositories of data by simply entering details of their product's inputs into a database and in turn being presented a $\mathrm{CO}_{2} \mathrm{e}$ number. ${ }^{12}$

The growth and increasing prominence of publicly available secondary data sources has in turn shaped how GHG emissions are being reduced. Here, the comparability of different products and processes enabled by databases threatens to conflate the reduction of

\footnotetext{
${ }^{12}$ A pattern exaggerated by the rise in corporate eco-design toolkits, which use LCA databases to appraise the relative merits of future product design (cf. Freidberg 2014; Meinrenken 2012)
} 
emissions with the disclosure of the right reduction numbers. Just as Schlamadinger and Marland $(2000,44)$ report that the US achieved a four percent reduction through 'certain changes in the way gas and sinks are calculated' so too retailers can achieve reductions through practices of counting. The result is an increased focus on those specific carbon reduction activities that can be clearly documented (through $\mathrm{CO}_{2} \mathrm{e}$ numbers) and communicated to retailers and brand-names, and in turn end consumers through the stories of the percentage of energy-use reduction or that of material input. Overall, this betrays a hidden carbon footprint counting complexity and politics, a challenge particular prevalent in understanding consumer use as discussed in depth in the next section.

\section{Constructing a 'counter-factual' consumption model for retail and consumer use}

The third and final significant component of a pint of semi skimmed milk's carbon footprint relates to how consumers buy ( $10 \%$ of total footprint occurs during retail), use ( $3 \%$ of total footprint) and then dispose (2\%) of it (Tesco 2008). As these activities occur at or after the point of purchase this data is often not available in a primary or a secondary format. Instead organizations are required to construct a series of counter-factual scenarios, or consumption models, which collectively predict what the consumer will do with the product (and the associated emissions) from the moment of purchase onwards. For instance will they walk back from the shops or drive? Will they boil the milk or drink it cold? How long will they refrigerate it for? How much will be wasted? Will they recycle the bottle?

In answering these questions, by collating multiple data sources and then transforming them into a single reality consumption models represent the third form of carbon counting boundary objects and indirectly enroll and speak on behalf of the consumer (Cf. Barnett et al. 2010). Yet, in doing so, and in stabilizing the reality of how a pint of milk is consumed, these models are especially reliant upon, and subject to, any number of deliberate or accidental approximations, assumptions, errors, discrepancies, omissions and/or other necessary 'fudge factors' (Lohmann 2005).

Firstly, calculating organizations are required to identify direct, indirect and proxy sources of data for each element of the consumption journey. For instance, in calculating the global warming impact of consumer travel to the retailer, Flysjö et al. (2011) used 2005 data from the Swedish Institute for Food and Biotechnology to estimate distance travelled and data collected by the Swedish Board of Agriculture in 2008 for total volume of groceries purchased. To calculate the carbon emitted in refrigerating the milk, Aurora Dairies (2010) combined data collected by USEIA in 2005 for annual refrigeration energy-use, with data collected five years later by USDA for per capita milk consumption. As these examples show, and this practitioner explains when describing the process for calculating consumer-use emissions, there remains a significant lack of consistency in post-retail data in terms of its 
availability and accuracy:

"... The problem is that where we have the biggest impact - is often the place where we have the weakest data ... Often the data is out of date; for the wrong country or based on the wrong technology. This introduces huge uncertainties and a certain level of 'wrong-ness' which we know is built into model - but what we don't know is how wrong..." Interview \#72

The shortage of accurate data for consumption behaviors has necessitated practitioners to adopt a certain degree of flexibility in their modeling through pragmatic assumptions and approximations. For instance, calculating consumer-use emissions for milk consumption in the US Thoma et al. $(2013,8)$ makes the assumption that "convenience stores, supermarkets, and mass merchandise outlets all have the same transportation distances and associated milk purchases", even though the authors acknowledge "it is likely that customers of convenience stores will typically purchase smaller quantities of milk and it is possible that there is an overestimate of the transportation burden for this sales channel". In another example, in calculating consumer travel emissions for a pint of milk, unable to access data for consumer travel in Denmark, Flysjö (2011) uses data from Sweden instead.

To address this chronic shortage of consumption data, other organizations have directly or indirectly enrolled consumers as carbon counters. For instance Coca-Cola (2013) conducted research with 20 UK and French households examining their recycling patterns. In 2011, Unilever conducted research into what British people do in the shower monitoring 2,600 showers taken by 100 families over ten days. Research conducted by the Tesco funded Sustainable Consumption Unit at Manchester University uses Tesco club card data to explore everyday consumption patterns (SCI 2012). However, whilst valuable for specific products, these individual data collection initiatives are contributing to a skewed landscape, with certain activities and industries able to report highly detailed up-to-date data, whilst others rely on typically less favorable historical or aggregated geographical data. For instance, countries with large dairy industries, in particular those with historical concerns about the impact of carbon footprinting disadvantaging their industries, have witnessed significant data collection activity over the past decade e.g. Australia (Dairy Australia 2012), New Zealand (Fonterra 2008), Sweden (Flysjo et al. 2011) and the UK (DairyCo 2012). In contrast there have been few, if any, studies on the carbon footprint of milk from African, or other developing, nations. Furthermore, the enrolment of consumers as carbon counters is also being undertaken to support certain low carbon commercial claims. For instance, a carbon audit by Ocado (a home-delivery service), perhaps unsurprisingly reported that delivering purchases to "consumers from a central storehouse generated less carbon per pound of sales than even walking to a traditional supermarket" (Ocado 2009).

Once the data has been identified, collected and or appropriated, calculating organizations 
must convert this aggregated data (e.g. energy used by a refrigerator, number of shopping trips per week) to the scale of an individual product unit (e.g. percentage of refrigerator energy used by pint of milk). Yet uncertainty remains. For instance should the total emissions associated with driving to the supermarket be allocated to individual products based on their mass (e.g. $600 \mathrm{ml}$ of milk is allocated double the emissions of $300 \mathrm{ml}$ of wine), by financial metrics (e.g. a $£ 10$ bottle of wine is allocated 20 times the emissions of $£ 0.50$ pint of milk), or by a different metric (e.g. based on $\mathrm{CO}_{2} \mathrm{e}$ emissions to the point of sale)? With emerging product carbon footprinting standards ${ }^{13}$ only offering guidance in the form of a hierarchy of allocation procedures, this decision has largely been left to the lead organization and/or consultant, again introducing a divergence between models. For example, Thoma et al. (2012) and Aurora Dairies (2010) allocated fuel for consumer travel based on sales percentage: An average consumer spends $£ 20$ per supermarket trip thus $£ 1$ spent on a liter of milk should receive $1 / 20^{\text {th }}$ (or $5 \%$ ) of the fuel emissions for the grocery trip. In contrast Flysjo et al. (2011) and WRAP (2010) allocated fuel for consumer travel based on 'mass': A household purchases $25 \mathrm{~kg}$ of food per shopping trip - thus one liter $(1 \mathrm{~kg})$ of milk would represent $1 / 25^{\text {th }}$ (or $4 \%$ ) of fuel emissions.

Just like the two preceding carbon counting boundaries objects, whilst these consumption models are vital in calculating the carbon footprint of a product, bridging the boundaries between different worlds and their counter-factual nature is premised on an assortment of assumptions. Specifically in enrolling and acting on behalf of consumers to stabilize how a pint of semi-skimmed milk is bought and consumed, they create one snapshot of everyday purchasing and consumption activities. When combined with the deficit of accurate and highquality data, these practitioner judgments and decisions lead to significant differences between studies. For instance, the results of two studies for the consumer use emissions of a pint of milk in the USA differed from approximately $120 \mathrm{gCO}_{2}$ e per pint $(11 \%$ of total footprint [Aurora Dairies 2010]) to approximately $58 \mathrm{~g} \mathrm{CO}_{2}$ e per pint (5\% of total footprint [Thoma et al. 2013]).

Finally, echoing the previous boundary objects, informed by these numbers, specific reduction actions can be accentuated such as enrolling consumers as carbon reduction agents through behavior changes such as recycling or walking to the store rather than other changes such as drinking less milk. For example, Tesco has labeled the carbon footprint of its skimmed, semi-skimmed, and full fat, organic and non-organic milk, enabling consumers to choose milk with a lower carbon footprint if they so choose. These labels also advise consumers "recycling this bottle reduces the carbon footprint by $40 \mathrm{~g}$ ". These specifically suggested actions and choices on the part of the consumer, as we discuss in our concluding comments, introduces important implications for how we manage the transition to a low carbon economy.

\footnotetext{
${ }^{13}$ (PAS 2050 - BSI 2010; ISO14067: 2013)
} 


\section{Conclusion: everyday carbon - do the parts equal the whole?}

To summarize, in answering this paper's two questions we have shown that the bold carbon commitments made by global retailers and brands have extended the practices of carbon counting and commensuration beyond iconic emissions to emissions of the 'everyday'. As such, whilst carbon may not, yet, represent a "salient consideration in the public's everyday decision-making" (Whitmarsh et al. 2011, 64), for retailers and their supply chains, carbon is rapidly becoming "a common denominator for thinking about the organization of social life in relation to the environment" (Bridge 2011, 821). We conclude with two points relating to the wider implications of product and service carbon footprinting within the new carbon economy.

Firstly, by turning the spotlight onto the everyday, non-iconic emission, product carbon footprinting has triggered a wave of supply-chain carbon literacy with the enrolment, or selfenrolment, of actors spanning farmers (and by association animals), consultants, dairy processors, suppliers, retailers and consumers. Behind these enrolments are a series of tools, models and databases, that abstract greenhouse gas emissions from the messiness of their everyday social and material realities. However, meeting multiple user requirements whilst simultaneously abstracting units of $\mathrm{CO}_{2} \mathrm{e}$ from varying degrees of un-cooperativeness means boundary objects must establish arbitrary categories and simplify complex methodological debates. In parallel, boundary objects are subject to the agendas of the worlds that they link with each enrolled actor inscribing different meaning to a product's carbon footprint in accordance with their specific subjectivities, commercial desires and epistemic framings. Indeed, and returning to Stamp's comment at the beginning of this paper, it is not just the "village watchman" but a whole host of actors who put down both "what he [sic] pleases..." and more notably 'what pleases him/them'. This has seen farmers speaking on behalf of their animals, industry associations representing their members, and perhaps most notably corporate-funded studies which speak on behalf of their consumers.

As a consequence the very plasticity of a boundary object which is necessary to navigate the complexities of turning things into numbers (Barnes and Hannah 2001) also serves to construct an ideologically and politically infused vision of what a product's footprint is. Further, and as demonstrated here with the pint of semi-skimmed milk, not only do these boundary objects produce particular representations of nature, but different boundary objects produce different representations, their choice being a form of politicized decision-making, and reflecting distinct ideologies of measurement. Most notably, the changeable plasticity of boundary objects and politicized practices of carbon counting links the ideology of measurement with the ideology of action. Here, echoing Lövbrand and Stripple (2011), we can extend the maxim of 'that which gets measured gets managed' into the new territory of how something is measured is how it gets managed. 
Secondly, through enrolling actors from field to fork, and by converting biological and social activities into stocks and flows of carbon, global retailers and brands are granted new scope outside their four walls to coordinate carbon reduction activities. Armed with these exact numbers and the 'e=equivalence' processes and discourses, and set within a landscape in which everything has a comparable carbon footprint, global corporations are, with increasingly confidence, announcing the emissions which they are responsible for and which their supply chain are responsible for. In relation to the pint of semi-skimmed milk, on a direct level, this has seen retailers promote specific supply chain carbon reduction actions centered on measurable reductions delivered through cost-carbon efficiency, market-led innovation and consumption-driven change. At a more fundamental level this sees an exporting of climate mitigation responsibility and risk along a product's supply chain, with retailers achieving their ambitious headline grabbing targets on the back of the labor-tied to various carbon truths (see Ormond, in press)—of their supply chains, whilst making minimal investment. This situation thus is clearly a new manifestation of Bumpus and Liverman's $(2008,134)$ notion of "accumulation by decarbonisation" facilitated by this new regime of carbon accounting.

As such, carbon counting, through product carbon footprinting, is more than a technical term or process: It refers to a form of rule that has given rise to particular ways of 'seeing' and 'knowing' the climate, in which carbon is attributed to stakeholders along the supply chain and expected to be managed. Boundary objects not only enable a product's carbon footprint to be made visible and knowable but they construct administrative domains and stabile framings, amenable to certain forms of political and economic rationality. However, the uncertainty, plasticity and 'wrong-ness' associated with the calculation of a product or service's carbon footprint, combined with the ideologically and politicized infused vision of how best to reduce a product's offers significant implications for the governance and management for this new carbon economy.

Crucially, product carbon footprinting raises important questions as to whether the carbon reduction strategies these numbers support are the most effective both in terms of cost or carbon reduction (e.g. Hillier 2011 and Lewis et al. 2013). Here we have highlighted the uncertainty involved in the practices of calculating the carbon footprint of a relatively simple product such as pint of milk. If we take this to the scale of the everyday shopping basket, this threatens to create a vast volume of 'uncoordinated' carbon at the global level. The danger here is that despite commendable commitments and reductions made by nations, global corporations and individuals - given the seemingly inevitable and/or imponderable 'wrongness' in each of these numbers - the result might be that the sum of the parts do not add up to the whole. With the ideology of measurement linked to the ideology of action and this new-found emphasis on those quantifiable and disclosed emissions and reductions within 
a supply chain, we are seemingly side-stepping a more confrontational engagement with the unsustainable consumption practices at the heart of climate change.

\section{REFERENCES:}

Agri-Assist, 2009. Carbon Tool. [Online] Available at: http://www.agriassist.co.uk/carbon tool [Accessed 25 $5^{\text {th }}$ May 2014].

AB Sustain, 2009. What we do - Greenhouse gas. [Online] Available at:

http://www.absustain.com/what-we-do/greenhouse-gas-modelling/greenhouse-gas/ [Accessed 25 ${ }^{\text {th }}$ May 2014].

Ascui, F., and Lovell, H., 2012. Carbon accounting and the construction of competence. Journal of Cleaner Production, 36, pg. 48-59.

Aurora, 2010. Aurora Organic Dairy - Corporate Sustainability Report. [Online] Available at: http://deepblue.lib.umich.edu/handle/2027.42/69242 [Accessed 25 ${ }^{\text {th }}$ May 2014].

Bailey, I., Gouldson, A., and Newell, P., 2011. Ecological modernisation and the governance of carbon: A critical analysis. Antipode, 43, pg. 682-703.

Bailey, I., and Wilson, G.A., 2009. Theorising transitional pathways in response to climate change: technocentrism, ecocentrism, and the carbon economy. Environment and planning $A$, 41(10), pg. 2324-2341.

Bakker, K., 2005. Neoliberalizing nature? Market environmentalism in water supply in England and Wales. Annals of the Association of American Geographers, 95(3), pg. 542-565.

Barnes, T.J., and Hannah, M., 2001. The place of numbers: histories, geographies, and theories of quantification. Environment and Planning D: Society and Space, 19, pg.379383.

Barnett, C., Cloke, P., Clarke, N., and Malpass, A., 2010. Globalizing responsibility: The political rationalities of ethical consumption. London: John Wiley \& Sons.

Bebbington, J., and Larrinaga-González, C., 2008. Carbon trading: accounting and reporting issues. European Accounting Review, 17(4), pg. 697-717.

Bowker, G.C., and Star, S.L., 1999. Sorting Things Out: Classification and its Consequences. Cambridge, MA: MIT Press.

Boykoff, M.T., and Goodman, M.K., 2009. Conspicuous redemption? Reflections on the promises and perils of the 'celebritization' of climate change. Geoforum, 40(3), pg. 395406.

Boyd, E., Boykoff, M., and Newell, P., 2011. The new carbon economy: what's new? Antipode, 43(3), pg. $601-611$.

Bridge, G., 2011. Resource geographies 1 Making carbon economies, old and new. Progress in Human Geography, 35(6), pg. 820-834. 
British Standards Institute (BSI), 2008. Publicly Available Specification (PAS) 2050 -. Specification for the assessment of the life cycle greenhouse gas emissions of goods and services. London: BSI.

Brown, K., and Corbera, E., 2003. Exploring equity and sustainable development in the new carbon economy. Climate Policy, 3(1), pg. 41-56.

Bullock, D., 2012. Emissions trading in New Zealand: development, challenges and design. Environmental Politics, 21(4), pg. 657-675.

Bumpus, A.G., 2011. The matter of carbon: understanding the materiality of tCO2e in carbon offsets. Antipode, 43(3), pg. 612-638.

Bumpus, A.G., and Liverman, D.M., 2008. Accumulation by decarbonization and the governance of carbon offsets. Economic Geography, 84(2), pg. 127-155.

Callon, M., 1986. Some elements of a sociology of translation: Domestication of the scallops and the fishermen of St. Brieuc Bay. Power, action, and belief: A new sociology of knowledge, 32, pg. 196-223.

Callon, M., 1998. An Essay on Framing and Overflowing: Economic Externalities Revisited by Sociology', in M. Callon (ed), The Laws of the Markets. Blackwell:Oxford, pp. 244-269.

Callon, M., 2009. Civilizing markets: carbon trading between in vitro and in vivo experiments Accounting, Organizations and Society, 34, pg. 535-48.

Carbon Trust. 2009. Carbon footprinting software. [Online] Available at: http://www.carbontrust.com/software [Accessed 23rd May 2014].

Carbon Trust. 2010. Guidelines for the Carbon Footprinting of Dairy Products in the UK. [Online] Available at: http://www.dairyco.org.uk/resources-library/researchdevelopment/environment/carbon-footprinting-dairy-products-in-theuk/\#.VM1RHWTzcaY [Accessed 25 ${ }^{\text {th }}$ May 2014].

Carbon Trust. 2013. Carbon Trust unlaces the 'carbon bootprint' of watching football. [Online] Available at http://www.carbontrust.com/about-us/press/2013/08/carbon-trust-unlacescarbon-bootprint-of-watching-football [Accessed $25^{\text {th }}$ May 2014].

Cardona, O.D., 2011. Disaster risk and vulnerability: Concepts and measurement of human and environmental insecurity. In: H.G., Brauch. U., Oswald Spring. C., Mesjasz. J., Grin. P., Kameri-Mbote. B., Chourou. P., Dunay. J., Birkmann. eds. 2011. Coping with Global Environmental Change, Disasters and Security. Berlin: Springer. pg. 107-121.

Cash, D.W., 2001. "In order to aid in diffusing useful and practical information": Agricultural extension and boundary organizations. Science, Technology \& Human Values, 26(4), pg. 431-453.

Casino, 2012. Encouraging consumption that respects the environment. [Online] Available at: http://www.groupe-casino.fr/en/Encouraging-consumption-that.html [Accessed $14^{\text {th }}$ May 2014].

Castree, N., 2003. Commodifying what nature? Progress in human geography, 27(3), pg. 273-297. 
Chagunda, M.G.G., Ross, D., and Roberts, D.J., 2009. On the use of a laser methane detector in dairy cows. Computers and Electronics in Agriculture, 68(2), pg. 157-160.

Chagunda, M.G.G., 2013. Opportunities and challenges in the use of the Laser Methane Detector to monitor enteric methane emissions from ruminants. Animal, 7(2), pg. 394400.

Clark, G.L., 1998. Stylized facts and close dialogue: methodology in economic geography. Annals of the Association of American Geographers, 88(1), p.73-87.

Coca-Cola, 2013. Recycle for the Future: Coca-Cola Enterprises seeks to transform at-home recycling. [Online] Available at: http://www.cokecce.com/news-and-events/news/recyclefor-the-future-coca-cola-enterprises-seeks-to-transform-at-home-recycling [Accessed $11^{\text {th }}$ September 2013].

Cook, A., 2008. Emission Rights: From Costless Activity to Market Operations. Accounting, Organizations and Society, 34(3-4), pg. 456-468.

Cool Farm Tool. 2013. Cool Farm Tool. [Online] Available at: www.coolfarmtool.org [Accessed 11 $1^{\text {th }}$ September 2013].

Dairy Australia. 2012. Carbon Footprint of the Australian Dairy Industry. PE Australasia and the Tasmanian Institute of Agriculture. [Online] Available at: www.dairyaustralia.com.au/ Animal_management_Environment_Climate_footprint.pdf [Accessed $14^{\text {th }}$ May 2014].

DairyCo. 2012. Greenhouse gas emissions on British Dairy farms. [Online] Available at: www.dairyco.org.uk/greenhouse gas emissions on british dairy farms.pdf [Accessed $11^{\text {th }}$ September 2013].

Dalsgaard, S., 2013. The commensurability of carbon: Making value and money of climate change. HAU: Journal of Ethnographic Theory, 3(1), pg. 80-98.

Dauvergne, P., and Lister, J., 2012. Big brand sustainability: Governance prospects and environmental limits. Global Environmental Change, 22(1), pg. 36-45.

Dean, M. 1999. Governmentality: Power and Rule in Modern Society. London: Sage.

Demeritt, D., 2001. Scientific forest conservation and the statistical picturing of nature's limits in the Progressive-era United States. Environment and Planning D: Society and Space, 19, pg. 431-459.

Department for Environment, Food and Rural Affairs (Defra), 2009. Methane emissions by individual dairy cows under commercial conditions. UK: DEFRA.

Descheneau, P., and Paterson, M., 2011. Between desire and routine: assembling environment and finance in carbon markets. Antipode, 43(3), pg. 662-681.

Descheneau, P., 2012. The currencies of carbon: carbon money and its social meaning. Environmental Politics, 21(4), pg. 604-620.

Eden, S., 2012. Counting fish: Performative data, anglers' knowledge-practices and environmental measurement. Geoforum, 43(5) pg. 1014-1023.

Elden, S., 2007. Governmentality, calculation, territory. Environment and Planning D: Society and Space 25(3), pg. 562-580. 
Ellis, R., and Waterton, C., 2005. Caught between the cartographic and the ethnographic imagination: the whereabouts of amateurs, professionals, and nature in knowing biodiversity. Environment and Planning D: Society and Space, 23, pg. 673-693.

Espeland, W.N., and Stevens, M.L., 1998. Commensuration as a social process. Annual review of sociology, 24, pg. 313-343.

Financial Times. 2007. Tesco to 'carbon label' its products. [Online] Available at http://www.ft.com/cms/s/0/966e2910-a765-11db-83e4 0000779e2340.html\#axzz324cjlxmx [Accessed 14 ${ }^{\text {th }}$ May 2014].

Finkbeiner, M., 2009. Carbon footprinting - opportunities and threats. The International Journal of Life Cycle Assessment, 14(2), pg. 91-94.

Flysjö. A., Henriksson, M., Cederberg, C., Ledgard, S., and Englund, J-E., 2011. The impact of various parameters on the carbon footprint of milk production in New Zealand and Sweden. Agricultural Systems, 104, pg. 459-469.

Flysjö, A., 2011. Potential for improving the carbon footprint of butter and blend products. Journal of dairy science, 94(12), pg. 5833-5841.

Fogel, C., 2005. Biotic carbon sequestration and the Kyoto Protocol: the construction of global knowledge by the Intergovernmental Panel on Climate Change. International Environmental Agreements: Politics, Law and Economics, 5(2), pg. 191-210.

Fonterra. 2008. Carbon Footprint Measurement. [Online] Available at: http://www.fonterra.com/wps/wcm/connect/944cee00415ae42c834eebd111458f1c/Carbo n\%2BFootprint\%2Bmethodology\%2Bfinal.pdf?MOD=AJPERES [Accessed $9^{\text {th }}$ September].

Food Bev. 2011. Asda's sugar-rich grass to confront cow carbon conundrum, October 12. [Online] Available at: http://www.foodbev.com/news/asdas-sugar-rich-grass-to-confrontcow-c\#.VPIGnbPzcaY

Freidberg, S., 2014. Footprint technopolitics. Geoforum, 55, pg. 178-189.

Ghenai, C., 2012. Life Cycle Assessment of Packaging Materials for Milk and Dairy Products. International Journal of Thermal and Environmental Engineering, 4(2), pg. 117-128.

Greenhouse Gas (GHG) Protocol. 2011. Product Life Cycle Accounting and Reporting Standard. USA: World Resources Institute and World Business Council for Sustainable Development.

Goodman, M., and Boyd, E., 2011. A social life for carbon?: Commodification, markets and care. The Geographical Journal, 177(2), pg. 102-109.

Guardian. 2010. What is the carbon footprint of ... a newspaper. [Online] Available at: http://www.theguardian.com/environment/green-living-blog/2010/nov/04/carbon-footprintnewspaper [Accessed 14 ${ }^{\text {th }}$ May 2014].

Gujba, H., and Azapagic, A., 2011. Carbon footprint of beverage packaging in the United Kingdom. In: M., Finkbeiner. eds. 2011 Towards life cycle sustainability management. Netherlands: Springer. Pg. 381-390. 
Gutiérrez, M., 2011. Making Markets Out of Thin Air: A Case of Capital Involution. Antipode, 43(3), pg. 639-661.

Hays, S., 1996. The cultural contradictions of motherhood. New Haven: Yale University Press.

Hillier, J., 2011. Developing carbon management strategies for HE institutions with extensive land holdings Evaluation of methodologies available for measuring and reducing carbon emissions. Shropshire: Harper Adams and HEFCE.

Hillier, J., Walter, C., Malin, D., Garcia-Suarez, T., Mila-i-Canals, L., and Smith, P., 2011. A farm-focused calculator for emissions from crop and livestock production. Environmental Modelling and Software, 26(9), pg. 1070-1078.

Hope, C., 2009. How deep should the deep cuts be? Optimal CO2 emissions over time under uncertainty. Climate Policy, 9(1), pg. 3-8.

Hughes, A., McEwan, C., and Bek, D., 2013. Retailers, supply networks and changing articulations of ethicality: lessons from Flower Valley in South Africa. Journal of Economic Geography, 13(2), pg. 211-230.

Hulme, M., and Mahony, M., 2010. Climate change: What do we know about the IPCC? Progress in Physical Geography, 34(5), pg. 705-718.

Independent. 2007. Tesco invests $£ 500 \mathrm{~m}$ to create 'green consumer revolution'. [Online] Available at: http://www.independent.co.uk/news/business/news/tesco-invests-163500mto-create-green-consumer-revolution-432797.html [Accessed 14 ${ }^{\text {th }}$ May 2014]. International Organisation of Standardisation (ISO). 2013. ISO 14067 Carbon footprint of products - requirements and guidelines for quantification and communication. Geneva: ISO.

IPCC. 2006. IPCC Guidelines for National Greenhouse Gas Inventories. Inter-governmental Panel on Climate Change. Hayama, Japan: Institute for Global Environmental Strategies. Kanter, J., 2007. Carbon trading: Where greed is green. International Herald Tribune, $20^{\text {th }}$ June 2007. Pg. 1-3.

Katz, C., 2004. Growing up global: Economic restructuring and children's everyday lives. Minnesota: University of Minnesota Press.

Knox-Hayes, J., 2010. Constructing carbon market spacetime: climate change and the onset of neo-modernity. Annals of the Association of American Geographers, 100(4), pg. 953962.

Koteyko, N., Thelwall, M., and Nerlich, B., 2010. From carbon markets to carbon morality: Creative compounds as framing devices in online discourses on climate change mitigation. Science Communication, 32(1), pg. 25-54.

Kwa, C., 2005. Local Ecologies and Global Science Discourses and Strategies of the International Geosphere-Biosphere Programme. Social Studies of Science, 35(6), pg. 923-950.

Lansing, D.M., 2012. Performing carbon's materiality: the production of carbon offsets and the framing of exchange. Environment and Planning A, 44(1), pg. 204-202. 
Lansing, D.M., 2013. Not all baselines are created equal: AQ methodology analysis of stakeholder perspectives of additionality in a carbon forestry offset project in Costa Rica. Global Environmental Change, 23(3), pg. 654-663.

Latour, B., 2005. Reassembling the Social: An Introduction to Actor-Network-Theory. Oxford: Oxford University Press.

Leach, M., and Scoones, I., 2013. Carbon forestry in West Africa: The politics of models, measures and verification processes. Global Environmental Change, 23(5), pg. 957-967.

Levi Strauss \& Co., 2009. A product life cycle approach to sustainability. [Online] Available at: http://www.levistrauss.com/sustainability/innovative-practices/planet/ [Accessed $14^{\text {th }}$ May 2014].

Lewis, K.A., Green, A., Warner, D.J., and Tzilivakis, J., 2013. Carbon accounting tools: are they fit for purpose in the context of arable cropping? International Journal of Agricultural Sustainability, 11(2), pg. 159-175.

Lohmann, L., 2005. Marketing and making carbon dumps: commodification, calculation and counterfactuals in climate change mitigation. Science as culture, 14(3), pg. 203-235.

Lohmann, L., 2009. Climate as investment. Development and Change, 40(6), pg. 1063-1083.

Loomis, 2011. First transportation services company to carry carbon reduction label. [Online] Available at: http://www.loomis.co.uk/newsroom/press-releases/431-first-transportationservices-company-to-carry-carbon-reduction-label.html [Accessed $14^{\text {th }}$ May 2014].

Lorenzoni, I., Nicholson-Cole, S., and Whitmarsh, L., 2007. Barriers perceived to engaging with climate change among the UK public and their policy implications. Global environmental change, 17(3), pg. 445-459.

Lövbrand, E., and Stripple, J., 2011. Making climate change governable: Accounting for carbon as sinks, credits and personal budgets. Critical Policy Studies, 5(2), pg. 187-200.

Lovell, H., and MacKenzie, D., 2011. Accounting for carbon: the role of accounting professional organisations in governing climate change. Antipode, 43(3), pg. 704-730.

Lovell, H., Bebbington, J., Larrinaga, C., and de Aguiar, T.R.S., 2013. Putting carbon markets into practice: a case study of financial accounting in Europe. Environment and Planning C: Government and Policy, 31(4), pg. 741-757.

MacKenzie, D., 2009. Making things the same: Gases, emission rights and the politics of carbon markets. Accounting, Organizations and Society, 34(3), pg. 440-455.

Madon, S., Sahay, S., and Sahay, J., 2004. Implementing property tax reforms in Bangalore: an actor- network perspective. Information and Organization, 14(4), pg. 269-95.

Mansfield, B., 2003. From catfish to organic fish: making distinctions about nature as cultural economic practice. Geoforum, 34, pg. 329-342.

McAfee, K., 1999. Selling nature to save it? Biodiversity and green developmentalism. Environment and Planning, 17, pg. 133-154.

Meinrenken, C.J., Kaufman, S.M., Ramesh, S., and Lackner, K.S., 2012. Fast carbon footprinting for large product portfolios. Journal of Industrial Ecology, 16(5), pg. 669-679. 
Miller, C., 2001. Hybrid management: boundary organizations, science policy, and environmental governance in the climate regime. Science, Technology and Human Values, 26(4), pg. 478-500.

Mitchell, T., 2002. Rule of experts: Egypt, techno-politics, modernity. Berkeley: University of California Press

Morrisons, 2011. UK dairy industry carbon footprint - Morrisons. [Online] Available at: http://www.morrisonscorporate.com/Global/0 FarmingPage/UK\%20Dairy\%20Industry\%20Carbon\%20Footpri nt.pdf [Accessed $10^{\text {th }}$ January 2015].

Murdoch, J., and Ward, N., 1997. Governmentality and territoriality: the statistical manufacture of Britain's 'national farm'. Political Geography, 16(4), pg. 307-324.

Nerlich, B., and Koteyko, N., 2009. Compounds, creativity and complexity in climate change communication: the case of 'carbon indulgences'. Global Environmental Change, 19(3), pg. 345-353.

Neuendorf, K.A., 2002. The Content Analysis Guidebook. Thousand Oaks, CA: Sage.

Newell, P., and Bumpus, A., 2012. The global political ecology of the clean development mechanism. Global Environmental Politics, 12(4), pg. 49-67.

Ocado, 2009. Ocado - A greener grocer. [Online] Available at http://www.ocado.com/webshop/content/information3/green [Accessed 14 ${ }^{\text {th }}$ May 2014].

Ormond, J., 2013. The transition to low carbon milk: Dairy Consumption and the changing politics of human-animal relations. In: E.J. Abbots, and M.A. Lavis, eds. 2013. Why we eat, how we eat: contemporary encounters between foods and bodies. Surrey, UK: Ashgate Publishing, Ltd.

Ormond, J., 2015. Product carbon footprinting: The politics, people and practices. PhD. King's College London.

Owen Illinois, 2010. O-l's Complete Life Cycle Assessment of Glass Brings Clarity to Carbon Footprint Conversation. [Online] Available at: http://investors.oi.com/phoenix.zhtml?c=88324\&p=irol-newsArticle \&ID=1420038\&highlight $=[$ Accessed $14^{\text {th }}$ May 2014].

Pan, Y., Birdsey, R.A., Fang, J., Houghton, R., Kauppi, P.E., Kurz, W.A., and Hayes, D., 2011. A large and persistent carbon sink in the world's forests. Science, 333(6045), pg. 988-993.

Paterson, M., and Stripple, J., 2012. Virtuous carbon. Environmental Politics, 21(4), pg. 563582.

Pe International. 2009. Product carbon footprint. [Online] Available at: http://www.peinternational.com/services-solutions/carbon-footprint/product-carbon-footprint/ [Accessed $9^{\text {th }}$ May 2014].

PETRA. 2010. New Study Gives "Green" Light to PET Bottles over Glass or Aluminum. [Online] Available at: http://petresin.org/news GreenLighttoPETBottles.asp [Accessed 9th May 2014]. 
Peters, G.P., 2008. From production-based to consumption-based national emissions inventories. Ecological Economics, 65(1), p.13-23.

Phadke, R., 2011. Resisting and reconciling big wind: Middle landscape politics in the New American West. Antipode, 43(3), pg. 754-776.

Plassmann, K., Norton, A., Attarzadeh, N., Jensen, MP., Brenton. P., Edwards-Jones, G. 2010. Methodological complexities of product carbon footprinting: a sensitivity analysis of key variables in a developing country context. Environmental Science and Policy, 13(5), pg. 393-404.

Pre, 2009. SimaPro / Reliable Databases and Methods. [Online] Available at: http://www.presustainability.com/databases [Accessed 14th May 2014].

Prudham, S., 2007. The fictions of autonomous invention: accumulation by dispossession, commodification and life patents in Canada. Antipode, 39(3), pg. 406-429.

Radin, M.J., 1993. Compensation and commensurability. Duke Law Journal, 43(1), pg. 56-86.

Robertson, M.M., 2000. No net loss: wetland restoration and the incomplete capitalization of nature. Antipode, 32(4), pg. 463-493.

Robertson, M.M., 2004. The neoliberalization of ecosystem services: wetland mitigation banking and problems in environmental governance. Geoforum, 35(3), pg. 361-373.

Sainsbury's. 2009. Sainsbury's Dairy Development Group. [Online] Available at: http://www.jsainsbury.co.uk/responsibility/case-studies/2009/sainsburys-dairy-development-group/ [Accessed $6^{\text {th }}$ September 2014].

Sarker, S., Sarker, S., and Sidorova, A., 2006. Understanding Business Process Change Failure: An Actor-Network Perspective. Journal of Management Information Systems, 23(1), pg.51-86.

Schlamadinger, B., and Marland, G., 2000. Land Use and Global Climate Change: Forests, Land Management and the Kyoto Protocol. Washington, DC: Pew Center on Global Climate Change

Schoenberger, E., 1991. The corporate interview as a research method in economic geography. The Professional Geographer, 43(2), p.180-189.

Schroeder, H., and Lovell, H., 2012. The role of non-nation-state actors and side events in the international climate negotiations. Climate Policy, 12(1), pg. 23-37.

Scottish Government, 2010. A Scottish farm-based greenhouse gas accounting tool for Scotland. [Online] Available at: http://www.scotland.gov.uk/Publications/2010/10/28083913/0 $\left[\right.$ Accessed $6^{\text {th }}$ September 2014].

Siebenhüner, B., 2003. The changing role of nation states in international environmental assessments-the case of the IPCC. Global Environmental Change, 13(2), pg. 113-123.

SIG Combibloc Obeikan, 2012. Comparative Life Cycle Assessment of beverage cartons. [Online] Available at: http://www.sig.biz/middle-east-and-africa/en/environment/life-cycleassessments/ [Accessed $10^{\text {th }}$ January 2014]. 
Simon, G.L., Bumpus, A.G., and Mann, P., 2012. Win-win scenarios at the climate development interface: Challenges and opportunities for stove replacement programs through carbon finance. Global Environmental Change, 22(1), pg.275-287.

Slocum, R., 2004. Polar bears and energy-efficient lightbulbs: strategies to bring climate change home. Environment and Planning D, 22, pg. 413-438.

Star, S.L., and Griesemer, J.R., 1989. Institutional ecology, 'translations', and boundary objects: amateurs and professionals in Berkeley's Museum of Vertebrate Zoology, 19071939. Social Studies of Science, 19, pg. 387-420.

Stern, N., 2007. The economics of climate change: The Stern review. Cambridge, UK: Cambridge University Press.

St Martin, K., 2005. Mapping economic diversity in the First World: the case of fisheries. Environment and Planning A, 37, pg. 959-979.

Sustainable Consumption Institute. 2012. Annual Report June 2011 - July 2012.

Tesco, 2007. Tesco, Carbon and the Consumer: speech given by Sir Terry Leahy to a joint Forum for the Future and Tesco event. [Online] Available at: http://www.tescoplc.com/plc/media/pr/pr2007/2007-01-18/ [Accessed $6^{\text {th }}$ September 2014].

Tesco, 2008. Working together for a sustainable future. [Online] Available at: http://www.dairyuk.org/component/docman/doc download/5893-emma-jones-carbonconference-presentation [Accessed $6^{\text {th }}$ September 2014].

Tesco, 2012. Tesco - Product Carbon Footprinting Summary. [Online] Available at: http://www.tescoplc.com/assets/files/cms/Tesco Product Carbon Footprints Summary(1) .pdf [Accessed 6 ${ }^{\text {th }}$ September 2014].

Thoma, G., Popp, J., Nutter, D., Shonnard, D., Ulrich, R., Matlock, M., and Adom, F., 2013. Greenhouse gas emissions from milk production and consumption in the United States: a cradle to grave life cycle assessment circa 2008. International Dairy Journal, 31, pg. 314.

Unilever, 2011. UK Sustainable Shower Study. [Online] Available at: http://www.unilever.co.uk/mediacentre/pressreleases/2011/sustainableshowerstudy.aspx [Accessed $27^{\text {th }}$ May 2014].

Ward, L., 2013. Eco-governmentality revisited: Mapping divergent subjectivities among Integrated Water Resource Management experts in Paraguay. Geoforum, 46, pg. 91102.

Walmart, 2010. Walmart Announces Goal to Eliminate 20 Million Metric Tons of Greenhouse Gas Emissions from Global Supply Chain. [Online] Available at: http://news.walmart.com/news-archive/2010/02/25/walmart-announces-goal-to-eliminate20-million-metric-tons-of-greenhouse-gas-emissions-from-global-supply-chain [Accessed $9^{\text {th }}$ September 2013].

Weidema, B.P., Thrane, M., Christensen, P., Schmidt, J., and Løkke, S., 2008. Carbon footprint. Journal of Industrial Ecology, 12(1), p.3-6. 
Whitbread, 2009. Whitbread PLC - CRC Participant Case Study. [Online] Available at: https://www.gov.uk/government/publications/crc-case-studies [Accessed 14th May 2014].

Whitmarsh, L., 2009. What's in a name? Commonalities and differences in public understanding of 'climate change' and 'global warming'. Public Understanding of Science, 18, pg. 401-420.

Whitmarsh, L., Seyfang, G., and O'Neill, S., 2011. Public engagement with carbon and climate change: To what extent is the public 'carbon capable'? Global Environmental Change, 21(1), pg. 56-65.

WRAP, 2010. Life cycle assessment of example packaging systems for milk. [Online] Available at: http://www.wrap.org.uk/content/life-cycle-assessment-example-packagingsystems-milk [Accessed $14^{\text {th }}$ May 2014]. 